\title{
PROFILE OF COLORECTAL TUMOR IN GASTROENTERO-HEPATOLOGY CENTER, DEPARTEMENT OF INTERNAL MEDICINE, DR SOETOMO HOSPITAL, SURABAYA
}

\author{
Husin Thamrin $^{1}$, Khafidhotul Ilmiah ${ }^{2}$, Ni Wajan Tirthaningsih ${ }^{3}$ \\ ${ }^{1}$ Department of Internal Medicine, Dr. Soetomo Hospital, ${ }^{2}$ Faculty of Medicine, Universitas Airlangga, ${ }^{3}$ Anatomic \\ Pathology Department, Dr. Soetomo Hospital, Surabaya, Indonesia
}

\section{ABSTRACT}

\begin{abstract}
Colorectal cancer has became burden in the world.The latest study shows that colorectal cancer is the third most common cancer in men and second most common cancer in women globally. There are difference characteristic of epidemiology in every countries. Moreover, there is no study that represents epidemiology of colorectal cancer in Indonesia yet, especially in East Java. The aim of this study was to describe colorectal tumor profile by age and gender in Gastroentero-Hepatology Center, Dr Soetomo Hospital. This study has received a certificate of Ethical Clearance No.273/Panke.KKE/IV/2015, a descriptive retrospective study. We collected data using medical records, and patients who have been colonoscopy examination and suspected colorectal tumor were included. There were 201 patients, divided to 100 males and 101 females. The peak of incidence was on 51-60 years old group, but on the 31-40 years old incidence of colorectal tumor was increased. The youngest patient was 17 years old. And tumors are more likely develop in distal area, especially in rectum. This study shows a different characteristic profile of colorectal tumor, where tumor is developed at young people and there is no significant difference between male and female for the incidence.
\end{abstract}

Keywords: Colon; rectum; tumor; age; gender

\section{ABSTRAK}

Kanker kolorektal telah menjadi beban bagi dunia. Studi terbaru menunjukkan bahwa kanker kolorektal adalah kanker paling umum ketiga pada pria dan kanker paling umum kedua pada wanita secara global.Namun, ada perbedaan karakteristik epidemiologi di setiap negara baik negara maju maupun berkembang. Selain itu, belum ada penelitian yang mewakili epidemiologi kanker kolorektal di Indonesia, terutama di Jawa Timur. Tujuan dari penelitian ini adalah untuk menggambarkan profil tumor kolorektal berdasarkan usia dan jenis kelamin di Pusat Gastroentero-Hepatologi, Rumah Sakit Dr Soetomo. Penelitian ini merupakan penelitian retrospektif deskriptif yang telah menerima sertifikat Lolos Uji Etik No.273/Panke.KKE/IV/2015. Kami mengumpulkan data menggunakan catatan medis pasien yang telah menjalani pemeriksaan kolonoskopi dan diduga mengidap tumor kolorektal. Ada 201 pasien, terdiri dari 100 pria dan 101 wanita. Puncak kejadian adalah pada kelompok 51-60 tahun, tetapi pada kelompok usia 31-40 tahun insiden tumor kolorektal terus meningkat. Pasien termuda berusia 17 tahun. Dan tumor lebih mungkin berkembang di daerah distal, terutama di rektum. Penelitian ini menunjukkan bahwa adanya profil karakteristik yang berbeda dari tumor kolorektal, di mana insiden tumor meningkat pada orang muda dan tidak ada perbedaan yang signifikan antara laki-laki dan perempuan untuk kejadian tersebut.

Kata kunci: Usus besar; rektum; tumor; usia; jenis kelamin

Correspondence: Husin Thamrin, Department of Internal Medicine, Dr. Soetomo Hospital, Surabaya, Indonesia. Phone: +6281216258599. E-mail: dokterhusinthamrin@gmail.com

pISSN:2355-8393 • eISSN: 2599-056x • doi: 10.20473/fmi.v56i1.18445

- Fol Med Indones. 2020;56:15-18 • Received 15 Apr 2019 • Accepted 17 Oct 2019

- Open access under CC-BY-NC-SA license • Available at https://e-journal.unair.ac.id/FMI/

\section{INTRODUCTION}

Colorectal cancer is one of the health problems in the world that continues to increase. Colorectal cancer is the third largest cancer in male and the second most for female in the world (Globocan 2012). Countries with increased cases of colorectal cancer are Australia, New Zealand, Western Europe, and Southern Europe
(Globocan 2012). The high prevalence of colorectal cancer in these countries is often associated with diet and lifestyle (Boyle \& Langman 2000, Hamilton \& Aaltonen 2000). In Indonesia, colorectal cancer is a cancer at 10th rank of all types of cancer (Sander 2012).

Unique facts that was happen is even though the incidence of colorectal cancer is higher in developed 
countries globally, but the mortality rate in developing countries is even higher. This fact shows that the survival of a person suffering from colorectal cancer is higher in developed countries compared to developing countries (Globocan 2012). Therefore, preventive and early detection measures are important to reduce mortality.

The description of an illness is important. But the data of colorectal tumor cases in Indonesia has still not been found (Pourhoseingholi 2014). If a disease has a high prevalence, preventive measures must be increased. So colorectal cancer which is a disease with increasing incidence should get more attention.

The aim of this study was to determine the characteristics of colorectal tumors based on age, sex and location of the tumor in Dr Soetomo General Hospital. Author hoped that by knowing this description, early screening can be carried out so that pre-cancerous lesions can be identified.

\section{MATERIALS AND METHODS}

This was a descriptive, retrospective, non- randomized trial study involving patient with suspected colorectal tumor (neoplastic) who received colonoscopy examination. We collected data from the patients' medical record during June 2013 until May 2015 at Gastroentero-Hepatology Center, Dr Soetomo Hospital, Surabaya. Samples were taken by total sampling.
Descriptive analysis was performed to determine the demographic patients' characteristics by age and gender. We also determine location of colorectal tumor. Descriptive analysis was measured by SPSS software.

\section{RESULTS}

There were 201 patients (100 males, 101 females) between June 2013 - May 2015. 55 patient from June until December 2013, 86 patient on 2014, and 60 patient during January-May 2015. Prevalence of colorectal tumor was fluctuative. We cannot evaluate the prevalence was increase or decrease every year, because the data was collected start from mid year and finish on mid year too. The data are shown in Fig. 1.

The demography and characteristic of the patients included in this study are shown in Table 1. Mostly patients' age (30,84\%) was 51-60 years and the second place was $31-40$ years group $(26.86 \%)$. The oldest patient in this study was female 87 years old, meanwhile the youngest was male 17 years old. The number of female patients $(50.18 \%)$ was higher than male patients $(49.73 \%)$, but the difference was not significance.

The distribution of tumor locations is shown in table 2 . The most tumors found in the rectum area were $52.07 \%$ (113 patients). While at least $(1$ case) is found in another place. Another place have meaning that the location of the tumor cannot be identified according to anatomical location, because it is measured from the distance of the stoma.

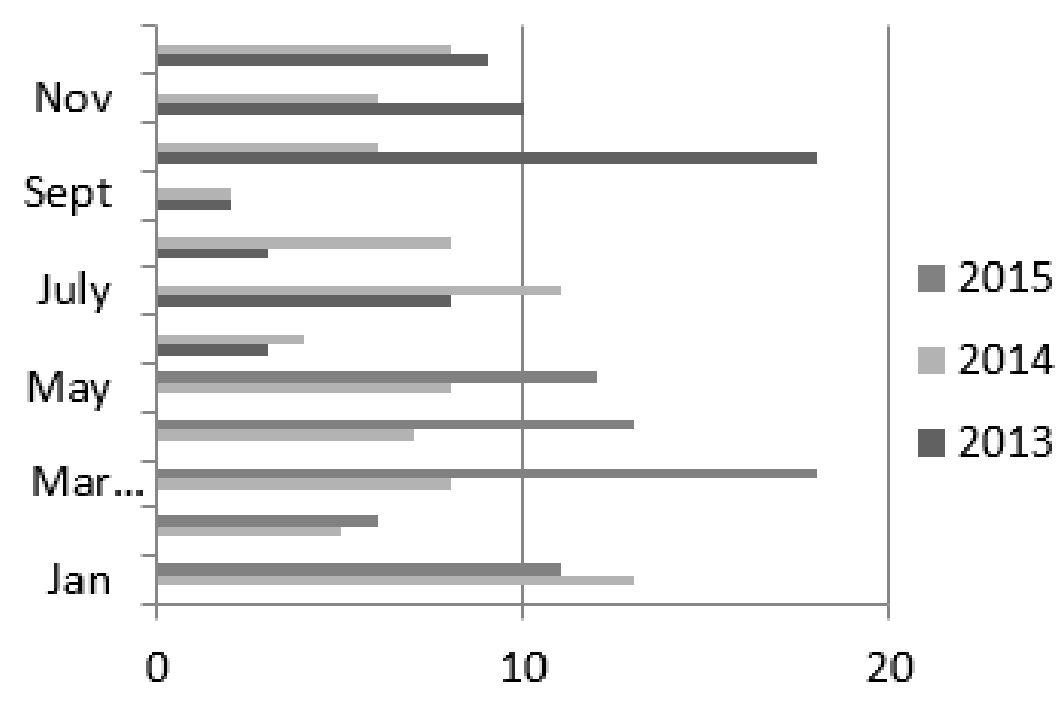

Fig. 1. Number of colorectal tumor patients from June 2013 to May 2015. 
Table 1. Demographic data

\begin{tabular}{ccccc}
\hline Age (year) & Male (n) & $\%$ & $\begin{array}{c}\text { Female } \\
(\mathrm{n})\end{array}$ & $\%$ \\
\hline $13-20$ & 1 & 0.5 & 1 & 0.5 \\
$21-30$ & 2 & 1 & 7 & 3.39 \\
$31-40$ & 13 & 6.47 & 10 & 4.98 \\
$41-50$ & 27 & 13.43 & 27 & 13.43 \\
$51-60$ & 32 & 15.97 & 30 & 14.93 \\
$61-70$ & 19 & 9.46 & 19 & 9.46 \\
$71-80$ & 4 & 1.99 & 4 & 1.99 \\
$81-90$ & 2 & 1 & 3 & 1.5 \\
\hline Total & 100 & 49.82 & 101 & 50.18 \\
\hline
\end{tabular}

Tabel 2. Distribution of tumor location

\begin{tabular}{lcc}
\hline \multicolumn{1}{c}{ Tumor Location } & $\mathrm{N}$ & $\%$ \\
\hline Anorectum & 3 & 1.38 \\
Rectum & 113 & 52.07 \\
Rectosigmoid & 29 & 13.36 \\
Colon sigmoid & 7 & 3.23 \\
Colon Desendence & 22 & 10.13 \\
Colon Transversum & 12 & 5.53 \\
Colon Asendence & 17 & 7.83 \\
Caecum & 7 & 3.23 \\
Ileocecal Junction & 6 & 2.76 \\
Other & 1 & 0.46 \\
\hline Total & 217 & 100 \\
\hline
\end{tabular}

\section{DISCUSSION}

Based on the study, the incidence of colorectal tumors increased in the age group 31-40 years (13 male and 10 female), then increased rapidly in the 41-50 year age group and reached the highest number of people at the age of 51-60 years (32 males and 30 females). This result shows that colorectal tumors tend to be diagnosed at the age of 30 years. Accordance with the prevalence in the United States. Where the diagnosis of colorectal cancer increases in the age group above 40 years (Haggar \& Boushey 2009).

The results showed that the youngest age for colorectal tumors was 17 years. Individuals who have a family history of colorectal cancer have a higher risk of developing cancer at a younger age than individuals without these risk factors (Kumar et al 2009). So the discovery of the youngest age in colorectal cancer is important to know for screening in individuals who have hereditary risk factors. Based on this study, author assume that a good age for early screening is 7 years, this is in line with Kumar et al's (2013) study which suggests that the journey of precancerous lesions to cancer takes 10 years.
Screening is an effective way to overcome health problems. According to Bradley et al (2011), a high screening rate is estimated can reduce colorectal cancer mortality, compared with adjuvant chemotherapy and reduction of risk factors. The risk factors are smoking, obesity, alcohol, and consumption of juncfood. The increase of screening rates can also reduce the estimated productivity-cost loss (Bradley et al 2011). Although the incidence rate is not significantly different, screening (with FOBT) in colorectal cancer can reduce mortality by almost $70 \%$ (Lee et al 2007). In Indonesia there are no data on colorectal cancer screening yet. Based on the description above, the authors recommend the existence of routine screening in Indonesia, especially in individuals who have hereditary factors.

The results of grouping the incidence of colorectal tumors by sex in this study didn't show a significant difference. This is different from the incidence of colorectal cancer cases in the world, where the cancer is more experienced by male. This is in line with the results of the cohort study in the Zaanstreek area of the Netherlands by Loeffeld et al (2013) which showed that male dominate the number of patients with colorectal cancer. 


\section{CONCLUSION}

Colorectal tumor profiles covering age and sex distribution at Dr. Soetomo Hospital's GastroenteroHepatology Center have different demographic characteristics with cancer profiles in other literature. Where there was an increased incidence at age above 31 years and there was no significant difference between the number of male and female sufferers. So, to reduce the mortality rate due to cancer, it is expected that in the future further research on colorectal cancer will be carried out and preventive measures initiated through early detection.

\section{REFERENCES}

Boyle P, Langman JS (2000). ABC of colorectal cancer epidemiology. British Medical Journal 321, 805-808

Bradley CJ, et al (2011). Productivity savings from colorectal cancer prevention and control strategies. Am J Prev Med 41, 1-16

Globocan (2012). Estimated cancer incidence, mortality and prevalence worldwide in 2012. Available at https://globocan.irc.fr/pages/fact_sheets_cancer.aspx? cancer=colorectal. Accessed at November, 112015
Haggar FA, Boushey RP (2009). Colorectal cancer epidemiology: Incidance, mortality, survival, and risk factors. Clinics in Colon and Rectal Surgery 22, 191197

Hamilton SR, Aaltonen LA (2000). Pathology and genetics of tumours of the digestive system. Lyon, France, International Agency for Research on Cancer

Kumar V, Abbas AK, Aster JC (2013). Robbins basic pathology 9th ed. Canada, Elsevier Saunders, p 592600

Lee KJ, et al (2007). Colorectal cancer screening using fecal occult blood test and subsequent risk of colorectal cancer: A prospective cohort study. Cancer Detect Prev 31, 3-11

Loeffeld, et al (2013). The incidence of colorectal cancer is decreasing in the older age cohorts in the Zaanstreek Region in Netherlands: an age cohort effect. ISRN Gastroenterology, 1-5

Pourhoseingholi MA (2014). Epidemiology and burden of colorectal cancer in Asia-Pasific Region: What shall we do now?. Transl Gastrointest Cancer 3, 169173

Sander MA (2012). Profil penderita kanker kolon dan rectum di RSUP Hasan Sadikin Bandung. Scientific Journal UMM 3 